\title{
Nanogold mesoporous iron promoted ceria catalysts for total and preferential $\mathrm{CO}$ oxidation reactions
}

\author{
Tomás Ramírez Reina ${ }^{1 *}$, Svetlana Ivanova ${ }^{1}$, Vasko Idakiev², Tatyana Tabakova ${ }^{2}$, Miguel Angel \\ Centeno ${ }^{1}$, Qing-Fang Deng ${ }^{3}$, Zhong-Yong Yuan ${ }^{3}$, José Antonio Odriozola ${ }^{1}$ \\ ${ }^{1}$ Departamento de Química Inorgánica e Instituto de Ciencias de Materiales de Sevilla Centro mixto \\ Universidad de Sevilla-CSIC, Avda. Américo Vespucio 49, 41092 Seville, Spain. \\ ${ }^{2}$ Institute of Catalysis, Bulgarian Academy of Sciences, Acad. G. Bonchev str., bl. 11, Sofia, 1113 \\ Bulgaria. \\ ${ }^{3}$ Key Laboratory of Advanced Energy Materials Chemistry (Ministry of Education), College of Chemistry, \\ Nankai University, Tianjin, China \\ (*) corresponding author: t.ramirez-reina@imperial.ac.uk
}

\begin{abstract}
Herein, a series of highly efficient gold based catalysts supported on mesoporous $\mathrm{CeO}_{2}-\mathrm{Fe}_{2} \mathrm{O}_{3}$ mixed oxides for $\mathrm{CO}$ elimination reactions have been developed. The materials have been fully characterized by means of XRD, Raman and UV-Vis spectroscopies among other techniques. We identify the Ce-Fe synergism as a fundamental factor controlling the catalytic performance. Our data clearly reveal that the $\mathrm{CO}$ oxidation activity is maximized when the electronic and structural properties of the support are carefully controlled. In this situation, fairly good catalysts for environmental applications as for example $\mathrm{H}_{2}$ streams purification for fuel cell goals or $\mathrm{CO}$ abatement at room temperature can be designed.
\end{abstract}

Keywords: Gold catalysts, mesoporous cerium oxide, low temperature $\mathrm{CO}$ oxidation, PrOx, $\mathrm{H}_{2}$ purification.

1 T.R.Reina actual address: Department of Chemical Engineering, Imperial College London. London SW7 2AZ, UK 


\section{Introduction}

Fuel cells have the potential to become an important energy conversion technology. The most successful fuel cells are powered by hydrogen [1]. Recently, research efforts directed toward the widespread and commercialization of fuel cells have accelerated the interest to develop a hydrogen-based economy to reduce oil use and decrease pollution [2]. However, hydrogen is difficult to store in a vehicle and to distribute from a centralized production facility. As a result, many efforts have been focused on the conversion of more readily available fuels to hydrogen, either on board a vehicle or for stationary applications. Currently hydrocarbons are employed to obtain hydrogen. The conversion of hydrocarbons to hydrogen is effected mainly by reforming [3]. However reforming processes produce carbon monoxide in association with hydrogen and carbon monoxide leads to a deactivation of the electrodes used in the fuel cell $[1,3]$. Therefore, $\mathrm{CO}$ abatement reactions such as CO oxidation [4], water gas shift (WGS) [5] and preferential CO oxidation (PrOx) [6] are of crucial relevance for the fuel cells and hydrogen economy development.

The WGS $\left(\mathrm{CO}+\mathrm{H}_{2} \mathrm{O} \rightleftarrows \mathrm{CO}_{2}+\mathrm{H}_{2}\right)$ not only reduces $\mathrm{CO}$ concentration but also produces hydrogen. Nevertheless, the WGS is an equilibrium-limited reaction making mandatory further clean-up processes for achieving the desirable levels of carbon monoxide in the gases feeding fuel cells $(<10 \mathrm{ppm})$. In this sense, the preferential oxidation with air of the pre-cleaned reformate (PrOx) represents a rather cheap and effective solution to abate the ultimate $\mathrm{CO}$ traces [7]. As $\mathrm{CO}$ and $\mathrm{H}_{2}$ oxidation may take place simultaneously, selectivity towards $\mathrm{CO}$ oxidation is one of the key aspects that should be targeted when facing the PrOx process. In addition, since the PrOx 
reactor will be feed with the pre-cleaned reformate gas, a suitable PrOx catalyst must tolerate high amounts of $\mathrm{CO}_{2}$ and $\mathrm{H}_{2} \mathrm{O}$ present in the reforming stream [8].

Gold catalysts have been broadly employed in such oxidation processes due to their high activity especially at low temperatures [9-14]. The activity of gold based catalysts at low temperature is an added value feature since normally their activity window matches the operation temperature of the fuel cell avoiding the conventional heating exchange steps. On the other hand, the performance of gold-based catalysts is known to be sensitive to the preparation method, the nature of the supports, the size of the gold particles and the interactions between the gold and the support. It is the later effect the one attracting most recent interest [15]. The presence of structural defects in the support surface as for example, oxygen vacancies, plays a determinant role in improving gold metallic dispersion influencing positively the $\mathrm{CO}$ oxidation activity [1619]. In addition, an adequate support should be able to avoid gold particles agglomeration, as well as to participate actively in the reaction mechanism by redox cycling of the support metal ions [20]. For all above, ceria-based materials are very attractive for supporting gold particles due to its ability for undergoing fast reduction/oxidation cycles since its intrinsic redox behavior $\left(\mathrm{Ce}^{4+} / \mathrm{Ce}^{3+}\right)$. This ability results in the formation of oxygen vacancies whose concentration is directly related to the catalytic activity [21]. In addition the number of oxygen vacancies available for oxidation reaction could be improved, either by specific surface area increase, e.g. the use of mesoporous ceria [22], by ceria deposition on the high surface supports to increase the surface/volume relation [23] or by doping ceria with different oxides [24]. Earlier studies found that $\mathrm{Au} / \mathrm{ceria}$ catalysts are very promising for the PrOx reaction [25-29]. We have recently reported that $\mathrm{ZnO}, \mathrm{ZrO}_{2}, \mathrm{Fe}_{2} \mathrm{O}_{3}$ and $\mathrm{Eu}_{2} \mathrm{O}_{3}$ are efficient dopants of $\mathrm{Au} /$ ceria system enhancing 
oxygen mobility, ceria reducibility, and in the end the catalytic performance in the PrOx process $[28,29]$.

Considering the above mentioned ways to increase the oxygen vacancies population, a detailed study of a series of gold based mesoporous mixed oxide catalysts $\left(\mathrm{Au} / \mathrm{CeO}_{2}-\mathrm{Fe}_{2} \mathrm{O}_{3}\right)$ is proposed. The samples are tested in the direct and preferential CO oxidation reactions in the present work, with main efforts focussed on achieving a further insight of the Ce-Fe interaction and its manifested relevance on the catalytic behaviour.

\section{Experimental}

\subsection{Catalysts preparation}

Mesoporous Ce-Fe composite oxides were prepared by surfactant-assisted method previously reported [30]. At room temperature, $6 \mathrm{mmol}$ of cetyltrimethylammonium bromide (CTAB) was dissolved into $200 \mathrm{~mL}$ distilled water, then calculated amount of $\mathrm{Ce}\left(\mathrm{NO}_{3}\right)_{3} \cdot 6 \mathrm{H}_{2} \mathrm{O}$ and $\mathrm{Fe}\left(\mathrm{NO}_{3}\right)_{3} \cdot 9 \mathrm{H}_{2} \mathrm{O}$ were added under vigorous stirring. After stirring for $0.5 \mathrm{~h}, 0.2 \mathrm{~mol} / \mathrm{L}$ sodium hydroxide solutions were gradually added into the above solution until the $\mathrm{pH}$ value of the mixed solution was 10, and then further stirred for about $12 \mathrm{~h}$. The final suspended solution was aged at $90{ }^{\circ} \mathrm{C}$ for $3 \mathrm{~h}$, washed with hot water several times, dried in the oven at $110{ }^{\circ} \mathrm{C}$ for $6 \mathrm{~h}$, then calcined at $400{ }^{\circ} \mathrm{C}$ for $4 \mathrm{~h}$. The as prepared series contains 6 samples where the $\mathrm{Ce} / \mathrm{Fe}$ molar ratio varies between 0-1. More precisely the supports corresponding to the following formulas are considered: $\mathrm{Ce}_{1} \mathrm{Fe}_{0} \mathrm{O}_{2}, \mathrm{Ce}_{0.8} \mathrm{Fe}_{0.2} \mathrm{O}_{2}, \mathrm{Ce}_{0.6} \mathrm{Fe}_{0.4} \mathrm{O}_{2}, \mathrm{Ce}_{0.4} \mathrm{Fe}_{0.6} \mathrm{O}_{2}, \mathrm{Ce}_{0.2} \mathrm{Fe}_{0.8} \mathrm{O}_{2}, \mathrm{Ce}_{0} \mathrm{Fe}_{1} \mathrm{O}_{2}$, which for briefness will be labeled for example Fe0Ce10, Fe2Ce8, etc. 
Gold catalysts were prepared by deposition-precipitation method in a "Contalab" (Contraves AG, Switzerland) reactor under full control of all parameters of preparation $(\mathrm{pH}$, temperature, stirring speed, reactant feed flow rates, etc.) as reported elsewhere [31]. Briefly, gold was deposited as $\mathrm{Au}(\mathrm{OH})_{3}$ onto mixed oxides thoroughly suspended in water via chemical interaction between $\mathrm{HAuCl}_{4} \cdot 3 \mathrm{H}_{2} \mathrm{O}$ and $\mathrm{K}_{2} \mathrm{CO}_{3}$, under vigorous stirring, while keeping constant $\mathrm{pH}$ 7. After filtering and careful washing, the precursors were dried under vacuum and calcined in air at $400{ }^{\circ} \mathrm{C}$ for 2 h. The nominal gold amount was 3 wt. \% Au.

\subsection{Catalyst characterization}

The actual gold loading was measured using atomic absorption spectroscopy (Varian Vista MPX).

X-ray diffraction (XRD) analysis was carried out on a X'Pert Pro PANalytical instrument. Diffraction patterns were recorded using $\mathrm{Cu} \mathrm{K} \alpha$ radiation $(40 \mathrm{~mA}, 45 \mathrm{kV})$ in a scanning range of $3-80^{\circ}(2 \theta)$ using step size of $0.05^{\circ}$ and step time of $240 \mathrm{~s}$. The diffraction peaks of the crystalline phase were compared to those of standard compounds reported in the JCPDS Date Base. The average crystallite size was calculated from the peaks width using Scherrer's equation.

$\mathrm{N}_{2}$ adsorption-desorption isotherms were collected at liquid nitrogen temperature using a Quantachrome NOVA 2000e sorption analyzer. The specific surface areas of the samples were calculated following the multi-point Brunauer-Emmett-Teller (BET) procedure. The pore-size distributions were determined from the adsorption branch of the isotherms using the BarettJoyner-Halenda (BJH) method. Before carrying out the measurement, each sample was degassed at $200{ }^{\circ} \mathrm{C}$ for more than $6 \mathrm{~h}$. 
The UV-Vis spectra were recorded on an Avantes spectrometer model AvaLight-DH-S-BAL and using $\mathrm{BaSO}_{4}$ as reference. All the spectra were collected in a diffuse reflectance mode and transformed to a magnitude proportional to the extinction coefficient through the KubelkaMunkfunction $\mathrm{F}(\alpha)$.

The Raman spectra were recorded in a dispersive HorivaJobin YvonLabRam HR800 Microscope, with a He-Ne green laser $(532.14 \mathrm{~nm})$ working at $5 \mathrm{~mW}$, and with a $600 \mathrm{~g} \cdot \mathrm{mm}^{-1}$ grating. The microscope used a 50x objective and a confocal pinhole of $1000 \mu \mathrm{m}$. The Raman spectrometer was calibrated using a silicon wafer.

\subsection{Catalytic activity and selectivity}

\section{CO oxidation}

The oxidation of $\mathrm{CO}$ was carried out in U-shape glass flow reactor at atmospheric pressure. The catalysts were pre-treated in a $30 \mathrm{~mL} \cdot \mathrm{min}^{-1}$ activation flow of $21 \% \mathrm{O}_{2}$ balanced in $\mathrm{He}$ (from room temperature to $\left.400{ }^{\circ} \mathrm{C}, 5^{\circ} \mathrm{C} \mathrm{min}^{-1}\right)$. After the activation a reactive flow $(3.4 \% \mathrm{CO}$ and $21 \%$ $\mathrm{O}_{2}$, balanced in helium) was passed through the reactor at room temperature. The total gas flow was fixed to $42 \mathrm{~mL} \cdot \mathrm{min}^{-1}$ and the quantitative analysis was carried out with Blazers OmnistarBentchop mass spectrometer calibrated using certified gas mixtures of $\mathrm{CO}$ and $\mathrm{CO}_{2}$ in helium. The weight hourly space velocity of the catalytic test was $31.5 \mathrm{~L} \cdot \mathrm{g}(\mathrm{cat})^{-1} \mathrm{~h}^{-1}$. The catalysts were tested in the reaction flow at room temperature until the steady state was reached. Then, the systems were heated to $400{ }^{\circ} \mathrm{C}$ at $5^{\circ} \mathrm{C} \cdot \mathrm{min}^{-1}$. To study in details the catalysts behaviour as a function of Fe-content the same reaction was carried out at temperatures below $0^{\circ} \mathrm{C}$. The reactor, loaded with fresh and activated sample, was immersed into cooling bath composed by 
liquid $\mathrm{N}_{2}$ and acetone. Once the temperature stabilized, the reactive flow was flushed through the reactor. The temperature was increased slowly to the room temperature and the quantitative analysis of the reactants and products was carried out on a Blazers OmnistarBentchop mass spectrometer. For the low temperature $\mathrm{CO}$ oxidation, all the samples were studied in the temperature range $-80-170{ }^{\circ} \mathrm{C}$.

Preferential CO oxidation (PrOx)

PrOx reaction was carried out at atmospheric pressure on a cylindrical fixed bed reactor of steel stainless $9 \mathrm{~mm}$ inner diameter), with $100 \mathrm{~mL} \cdot \mathrm{min}^{-1}$ of reaction feed composed by $1 \% \mathrm{CO}, 1.5 \%$ $\mathrm{O}_{2}, 10 \% \mathrm{CO}_{2}, 10 \% \mathrm{H}_{2} \mathrm{O}, 50 \% \mathrm{H}_{2}$ and $\mathrm{He}$ as balance. For each test $100 \mathrm{mg}$ of catalyst sieved between 100-200 $\mu \mathrm{m}$ was load. Prior to the catalytic measurements, the samples were treated in $100 \mathrm{~mL} \cdot \mathrm{min}^{-1}$ flow of $21 \% \mathrm{O}_{2}$ in $\mathrm{He}$, at $300{ }^{\circ} \mathrm{C}$ for $1 \mathrm{~h}$. Water vapor was added in the dry gas stream via syringe pump Gilson 307. Products and reactants were separated and quantified by on-line gas chromatography (Agilent 6890) equipped with HP PLOT Q and HP-5 columns and TCD detector.

The $\mathrm{CO}$ conversion was calculated according to Eq. (1) where $\mathrm{CO}_{\text {in }}$ is the amount of the $\mathrm{CO}$ in the inlet and $\mathrm{CO}_{\text {out }}$ that of the outlet

$$
\text { CO conversion }(\%)=\frac{C O_{\text {in }}-\mathrm{CO}_{\text {out }}}{C O_{\text {in }}} \times 100
$$

The selectivity towards $\mathrm{CO}_{2}$ formation was calculated with the Eq. (2). $\mathrm{O}_{2 \text { in }}$ corresponds to oxygen in the inlet and $\mathrm{O}_{2 \text { out }}$ to that in the outlet.

$$
\text { selectivity }(\%)=\frac{\left(\mathrm{CO}_{\text {in }}-\mathrm{CO}_{\text {out }}\right) \times 100}{2 \times\left(\mathrm{O}_{2 \text { in }} \mathrm{O}_{2 \text { out }}\right)}
$$




\section{Results and discussion}

\section{1 $\mathrm{N}_{2}$ Adsorption isotherms}

The isotherms of all Ce-Fe composite oxides and catalysts (Figure 1A, C) present the characteristic profile of typical mesoporous materials. An increase in $\mathrm{N}_{2}$ adsorption volume, located in the $\mathrm{p} / \mathrm{p}_{\mathrm{o}}$ range of $0.7-1.0$ is observed. The pore volume of all Ce-Fe mixed oxides is higher than that of pure $\mathrm{CeO}_{2}$ and $\mathrm{Fe}_{2} \mathrm{O}_{3}$ (Table 1). The gold addition provokes slight decrease of the pore volume, suggesting that the material kept its mesoporous structure after the gold deposition. The pore size distribution (Figure 1B, D) follows the same trend. The pore size of the solids appears to be affected by the sample composition. Gold deposition causes insignificant decrease of the pore size for $\mathrm{Au} / \mathrm{Fe} 2 \mathrm{Ce} 8$ and $\mathrm{Au} / \mathrm{Fe} 4 \mathrm{Ce} 6$, whilst a slight increase is observed for the other catalysts. This increase in the pore size was previously observed and ascribed to the nucleation of gold nanopartilces inside the pores of the support expanding the mesopore spacing $[32,33]$. The catalyst's specific surface area is also influenced by the support composition (Table 1). The increase of the nominal Fe concentration causes a gradual decrease of $S_{\mathrm{BET}}$ whereas gold deposition affects unimportantly the specific surface area. Indeed as shown in Figure 2A, the specific surface area reaches a maximum for both gold catalysts and supports at Fe2Ce8 composition. Rather similar trend was found for the catalysts gold uptake (Figure 2B). The intermediate formulations $\mathrm{Fe} 2 \mathrm{Ce} 8, \mathrm{Fe} 4 \mathrm{Ce} 6$ and $\mathrm{Fe} 6 \mathrm{Ce} 4$ allow higher capacity for gold incorporation. As indicated by Moreau et al. gold uptake strongly depends on the point of zero charge (PZC) of the support where gold is anchored, always considering the $\mathrm{pH}$ of the media during the synthesis procedure [34]. For basic $\mathrm{pH}$ values, taking into account the adsorption of the anionic species, lower the PZC of the support lower the uptake, an effect confirmed by the lower gold loading for pure hematite sample in comparison to ceria (5-6 vs. 6-7 ) [35]. For all the 
mixed samples, however, the gold uptake is always superior to the hematite and ceria pure supports. It could be due either to the increase of the specific surface of the oxides or to a second reason which might explain the gold enrichment observed for those samples. As commented in the introduction part, the use of appropriate dopants usually leads to the formation of oxygen vacancies on the ceria structure. These vacancies are viewed as electron rich sites where gold particles tend to nucleate [28]. Therefore, the enhanced gold uptake observed for the doped ceria samples could suggest higher concentration of oxygen vacancies on these mixed systems compared to the monometallic compositions.

\subsection{XRD}

The XRD patterns are presented in Figure 3A, B, for the supports and gold catalysts, respectively. For the supports, all the diffractions could be assigned either to face-centered cubic fluorite structure of ceria with cell parameter $\mathrm{a}=0.541 \mathrm{~nm}$ (\# JCPDS File 034-0394) or to hematite, $\alpha-\mathrm{Fe}_{2} \mathrm{O}_{3}$, (\# JCPDS File 033-0664). The progressive addition of $\mathrm{Fe}_{2} \mathrm{O}_{3}$ to ceria causes broadening and shifts of the ceria diffractions toward higher 2theta angles, the later suggesting a solid solution like formation, proof being the $\mathrm{Fe} 2 \mathrm{Ce} 8$ sample, for which the absence of the hematite phase is accompanied by the ceria lattice parameter decrease. The decrease of the lattice parameter originates the contraction of the unit cell due to the possible substitution of $\mathrm{Ce}^{4+}(0.97$ $\AA$ ) by $\mathrm{Fe}^{3+}$ with quite lower ionic radius $(0.64 \AA)$ and reveals formation of a cubic $\mathrm{CeO}_{2}$-like solid solution for this sample. Starting from Fe4Ce6 sample, weak diffractions related to hematite, appeared in the XRD pattern. For this sample the coexistence of Ce-Fe solid solution and $\mathrm{Fe}_{2} \mathrm{O}_{3}$ oxide could be imagined. A further increase of iron oxide concentration leads to an increase of the relative contribution of this phase, and consequently decreases that of ceria. For 
the ceria containing gold catalysts, weak and broad diffraction at $2 \theta=38.2^{\circ}$ are registered and correspond to an average gold particles size of $6 \pm 0.5 \mathrm{~nm}$, calculated from Scherrer's equation on the (111) crystallographic plane (Table 1).

\subsection{Raman spectroscopy}

Figure 4A shows the Raman spectra of the prepared supports. For pure $\mathrm{CeO}_{2}(\mathrm{Fe} 0 \mathrm{Ce} 10)$ sample the spectrum is dominated by the band centred at $460 \mathrm{~cm}^{-1}$ assigned to the $F_{2 g}$ Raman active mode of $\mathrm{CeO}_{2}$ fluorite structure, which can be described as symmetric breathing mode of the oxygen atoms around $\mathrm{Ce}^{4+}$ ions. The bands at 257,602 , and $1044 \mathrm{~cm}^{-1}$ arise from the mixing of $\mathrm{A}_{1 \mathrm{~g}}, \mathrm{Eg}$, and $\mathrm{F}_{2 \mathrm{~g}}$ vibrational modes of the ceria lattice, due to second-order transverse acoustic mode, defect-induced mode, and second-order longitudinal optical mode, respectively [36, 37]. The band at $602 \mathrm{~cm}^{-1}$ is generally associated with the presence of ceria lattice defects, e.g. oxygen vacancies, preferentially placed within the cubic structure [36]. Detailed analysis (Figure 4C) reveals the presence of weak bands situated at around $834,852,1171,1322,1620 \mathrm{~cm}^{-1}$.The band at $1171 \mathrm{~cm}^{-1}$ is due to $\mathrm{O}-\mathrm{O}$ stretching of adsorbed superoxide species $\left(\mathrm{O}_{2}^{-}\right)$while the bands at 852 , and $834 \mathrm{~cm}^{-1}$ can be assigned to $\mathrm{O}-\mathrm{O}$ stretching of peroxide adsorbed species $\left(\mathrm{O}_{2}{ }^{2-}\right)$ with different degrees of defect aggregation [37]. The band at $1620 \mathrm{~cm}^{-1}$ suggests molecular oxygen adsorption and that above $1300 \mathrm{~cm}^{-1}$ could be assigned to $\mathrm{O}_{2}{ }^{\delta-}(0<\delta<1)$ adspecies [38]. The presence of all those bands suggests that the adsorption equilibrium $\mathrm{O}_{2(\mathrm{~g})} \leftrightarrow \mathrm{O}_{2(\mathrm{a})} \leftrightarrow \mathrm{O}_{2}^{\delta-} \leftrightarrow \mathrm{O}_{2}{ }^{-} \leftrightarrow$ $\mathrm{O}_{2}^{2-}$ exists on the ceria surface. In general as an approach for comparing the defect population concentration between the samples the relation between the intensity of the bands at $602 \mathrm{~cm}^{-1}$ and 462 could be used. However, for the mixed CeFe oxide this approach is not fully accurate due to 
the presence of one visible band (Eg mode) of hematite structure $\left(605 \mathrm{~cm}^{-1}\right)$. In any case, the apparent increase of the $\mathrm{I}_{602} / \mathrm{I}_{462}$ relation for the Fe2Ce8 sample, suggesting a structural oxygen vacancies formation could be clearly discerned by the absence of all other expected hematite modes for this sample (Figure 4B). The later indicates high vacancies population for this sample, confirmed by the solid solution detection and absence of other iron containing phases observed by XRD and backing up the correlation between with the enhanced gold uptake of the mixed samples and the presence of oxygen vacancies. Further increase of iron results in the progressive mixing of the ceria and hematite Raman modes till the pure hematite sample where all predicted Raman modes by the group theory for iron oxide are observed (Figure 4B) [39].

The addition of gold does not change the Raman spectra of the samples (Figure not shown) only resulting in slight fluorescence of the sample caused by the gold presence.

\subsection{UV-Vis}

Further information concerning the electronic properties of the materials was obtained through UV-VIS spectroscopy. The diffuse reflectance spectra of the prepared supports are presented in Figure 5A. All the ceria containing samples present a broad absorption band centred at $291 \mathrm{~nm}$ ascribed to the charge transfer from $2 \mathrm{p}$ valence band of $\mathrm{O}^{2-}$ to $4 \mathrm{f}$ band of $\mathrm{Ce}^{4+}[40]$. This band is slightly shifted and widened when small amounts of Fe are included in the catalyst evidencing the $\mathrm{Ce}-\mathrm{Fe}$ interaction that results in sensitive modifications of the ceria electronic properties. For larger amount of $\mathrm{Fe}$ this band disappears and the spectra get closer to that of the pure $\mathrm{Fe}_{2} \mathrm{O}_{3}$. Indeed typical absorption bands of iron oxide sequentially appear in the spectra when the $\mathrm{Fe}$ loading increases. For example, the absorptions between 300 and $400 \mathrm{~nm}$ were previously 
assigned to oligomeric $\mathrm{Fe}_{\mathrm{x}} \mathrm{O}_{\mathrm{y}}$ clusters [41]. In the visible region (>450 nm), several adsorption bands (475 and $530 \mathrm{~nm}$ ) characteristic of d-d ${ }^{6} \mathrm{~A}_{1 \mathrm{~g}} \rightarrow{ }^{4} \mathrm{~T}_{1 \mathrm{~g}}$ and ${ }^{6} \mathrm{~A}_{1 \mathrm{~g}} \rightarrow{ }^{4} \mathrm{~T}_{2 \mathrm{~g}}$ transitions in $\alpha-\mathrm{Fe}_{2} \mathrm{O}_{3}$ are also detected [40]. Moreover, in order to evaluate the influence of iron oxide in ceria electronic structure, the spectra of all the Fe containing samples were deducted respect to the Fe0Ce10 sample allowing a better imaging of the Fe contribution (Figure 5B). The subtracted spectra are also factorized to compensate the differences in the Fe loading. In this situation, some new bands related to pure hematite $\left(\mathrm{Fe}_{2} \mathrm{O}_{3}\right)$ in the UV region $(<300 \mathrm{~nm})$ showed up. In particular, the bands at 300 and $270 \mathrm{~nm}$ attributed to $\mathrm{O}-\mathrm{Fe}^{3+}$ charge transfer transitions of isolated Fe ions in tetrahedral and octahedral coordination [42]. This transfer occurs from the highest lying $\mathrm{O} 2 \mathrm{p}$ orbitals to the half occupied Fe $3 d$ levels $\left(t_{2 g} \rightarrow e_{g} O_{h}\right.$ symetry and $t_{2} \rightarrow e T_{d}$ symetry). Very interestingly, among the mixed systems the Fe2Ce8 system seems to be the solid with the most notoroius iron influence since the iron oxide bands after substaction are rather prominents. Previous study with comparable systems also indicates that the strongest $\mathrm{Ce}-\mathrm{Fe}$ interaction is attained for this iron loading resulting in a satisfactory modification of the electronic properties of the catalysts [40].

As for the gold based catalysts Figure 5C presents the UV-Vis spectra. A new absorption band is found showing a maximum in the range $550-600 \mathrm{~nm}$ for some of the samples. This contribution is assigned to the well-known plasmon resonance of the gold nanoparticles [43]. In our case, such a feature was only detectable for the low iron loadings (Fe0Ce10 and Fe2Ce8). When the iron amount increases, the gold contribution is masked by the extended absorption of iron oxide in the visible region due to d-d transitions commented above. 


\subsection{Total CO oxidation}

Figure 6A shows the $\mathrm{CO}$ oxidation activity of the prepared samples. All the catalysts reached total CO conversion in the studied temperature range, however we can clearly distinguish between the $\mathrm{Au}-\mathrm{Ce}$ based systems and the $\mathrm{Au}-\mathrm{Fe}$ one. All the Ce-contained solids totally abated $\mathrm{CO}$ before $120^{\circ} \mathrm{C}$ whereas the $\mathrm{Au} / \mathrm{Fe}$ solid reached full conversion at $205^{\circ} \mathrm{C}$. The later evidences the role played by the support. Despite both $\mathrm{CeO}_{2}$ and $\mathrm{Fe}_{2} \mathrm{O}_{3}$ are considered as an active supports according to Schubert [44] it seems that ceria presence in the catalyst formulation leads to superior $\mathrm{CO}$ oxidation activity.

As all the ceria-based catalysts presented comparable results in a typical light-off experiment, a low temperature $\mathrm{CO}$ oxidation test was carried out in order to establish some differences among the samples (Figure 6B). As a general tendency, the CO conversion curves shifted to lower temperatures when the reaction takes places under sub-ambient temperatures irrespectively of support composition. In other words, apparently the catalysts presented a major capacity for CO oxidation when they are tested at low temperatures, either due to facilitated $\mathrm{CO}$ adsorption or to gold particles re-dispersion. Recently, similar results for $\mathrm{Au} / \mathrm{FeO} \mathrm{O}_{\mathrm{x}} / \mathrm{CeO}_{2}-\mathrm{Al}_{2} \mathrm{O}_{3}$ catalysts were reported [29]. A remarkable decrease of the gold particle size when the reaction was carried out at sub-ambient temperature was found in such paper, the occurring gold re-dispersion at this temperature provides more active sites for the oxidation and as a consequence enhances the catalytic activity. The same phenomena could explain the activity in this series of catalysts at low temperature where the $\mathrm{Au} / \mathrm{Fe} 2 \mathrm{Ce} 8$ system is the most active and the $\mathrm{Au} / \mathrm{Fe}$ system remains the 
less active sample. In addition, as indicated above the $\mathrm{Au} / \mathrm{Fe} 2 \mathrm{Ce} 8$ is the system with the largest $\mathrm{S}_{\mathrm{BET}}$ thus proving higher surface for gold re-dispersion and improving the overall performance. In order to compare quantitatively the activity of our systems with similar catalysts proposed by other authors, the specific reaction rates at $0{ }^{\circ} \mathrm{C}$ and $25^{\circ} \mathrm{C}$ and turnover frequencies (TOF), using the dispersion of $\mathrm{Au}$ atom exposure to reactants flow, are calculated and presented in Table 2. The dispersion of the gold nanoparticles considered as the active sites in the reaction is evaluated on the basis of the model of semihemispheric ball [45] and is presented together with the gold particle size in Table 2. From the table we can deduce that all the Ce-Fe mixed systems exhibit higher $\mathrm{CO}$ oxidation activities compared to the $\mathrm{Au} / \mathrm{Ce}$ and the $\mathrm{Au} / \mathrm{Fe}$ samples. The later underlines the impact on the Ce-Fe interaction which has been demonstrated by the characterization data. Again, TOF and reaction rates values confirm that $\mathrm{Au} / \mathrm{Fe} 2 \mathrm{Ce} 8$ is the best system within the series. Its reaction rate at $0{ }^{\circ} \mathrm{C}$ expressed as $\mathrm{mol}_{\mathrm{CO}} \cdot \mathrm{mol} \mathrm{Au}^{-1} \mathrm{~s}^{-1}\left(5.83 \times 10^{-2}\right)$ is superior to that reported by Kung et al. [46] for a $\mathrm{Au} / \mathrm{CeO}_{2}$ sample and to those of $\mathrm{Au} / \mathrm{Fe}_{2} \mathrm{O}_{3} / \mathrm{Al}_{2} \mathrm{O}_{3}$ and $\mathrm{Au} / 0.5 \mathrm{Fe}_{2} \mathrm{O}_{3} / \mathrm{CeO}_{2}-\mathrm{Al}_{2} \mathrm{O}_{3}$ catalysts reported in ref. [29] at $25^{\circ} \mathrm{C}$.

According to XRD, Raman and UV-Vis data this system presents the strongest Ce-Fe contact thus favouring the creation of higher amounts of oxygen vacancies in the ceria lattice that are responsible for the activity enhancement. In any case, the nanogold catalysts supported on Ce-Fe mixed oxides presented rather good ability for $\mathrm{CO}$ oxidation even at sub-ambient temperatures indicating the suitability of these catalysts for environmental applications as for example, $\mathrm{CO}$ depletion in contaminated atmospheres. 


\subsection{Preferential CO oxidation (CO-PrOx)}

The catalytic activity of the prepared gold based catalyst in the CO-PrOx reaction is presented in Figure 7A. It should be pointed out that the PrOx study was carried out using a surrogate reforming gas mixture including $\mathrm{CO}_{2}$ and $\mathrm{H}_{2} \mathrm{O}$. In principle, both $\mathrm{CO}_{2}$ and $\mathrm{H}_{2} \mathrm{O}$ may damage the catalytic performance for several reasons. For example, the presence of $\mathrm{CO}_{2}$ frequently leads to the formation of carbonaceous species in the catalyst surface acting as reactants sites blockers [47]. On the other hand, the presence of steam tend to slow down the $\mathrm{CO}$ oxidation rate of the gold based catalysts as previously demonstrated by Haruta et al. [48]. Besides, both $\mathrm{CO}_{2}$ and $\mathrm{H}_{2} \mathrm{O}$ could physically obstruct the arrival of $\mathrm{CO}$ to the catalyst's active sites due to the unavoidable competitive adsorption. Despite all the drawbacks introduced by these molecules, our catalysts resulted very efficient in the preferential $\mathrm{CO}$ oxidation. Again, as observed for the direct $\mathrm{CO}$ oxidation, the systems with an optimal $\mathrm{Ce}-\mathrm{Fe}$ contact are especially active. For instance, $\mathrm{AuFe} 2 \mathrm{Ce} 8$, AuFe4Ce6 and AuFe6Ce4 reached very high $\mathrm{CO}$ conversion at low temperature. This observation highlights one of the main ideas of this paper: the catalytic skills of nanogold based catalysts can be boosted by modulating the physicochemical properties of the support. In particular for mesoporous ceria based solids the creation of oxygen vacancies and the modification of the electronic density due to the formation of mixed oxides with Fe benefits in a great extent the activity in oxidation reactions. The superiority of the mixed systems is evidenced in view of the relatively poor activity presented by $\mathrm{Au} / \mathrm{Fe} 0 \mathrm{Ce} 10$ and $\mathrm{Au} / \mathrm{Fe} 10 \mathrm{Ce} 0$ especially at low temperature (under $120{ }^{\circ} \mathrm{C}$ ). In fact, $\mathrm{Au} / \mathrm{Fe} 0 \mathrm{Ce} 10$ showed good activity in the high temperature range indicating that the positive effect obtained from the Ce-Fe interaction is more relevant at low temperature in good agreement with the results obtained in the total $\mathrm{CO}$ oxidation. 
Regarding the selectivity, Figure 7B shows the selectivity curves obtained during the PrOx test. All the catalysts presented a similar trend, the selectivity towards $\mathrm{CO}$ oxidation decreases when the temperature increases. The latter is in line with the most of the literature data involving gold based catalysts for the $\mathrm{CO}-\mathrm{PrOx}$ and could be explained in terms of the competitive $\mathrm{H}_{2} / \mathrm{CO}$ oxidation processes [49-51]. Carbon monoxide oxidation is favoured at low temperature and gold based catalysts are very promising systems in this regard allowing high CO oxidation rates no matter the gas stream (direct or preferential CO oxidation environments). Nevertheless, when the temperature increases, $\mathrm{H}_{2}$ combustion becomes energetically more favourable and starts to control the selectivity of the overall process. In a recent publication we analysed in details the $\mathrm{CO} / \mathrm{H}_{2}$ competition via pulses experiments reaching the conclusion that at low temperature $\mathrm{CO}$ is able to displace $\mathrm{H}_{2}$ from the surface and reach the actives sites of the catalyst and subsequently react. However, this ability of $\mathrm{CO}$ to remove hydrogen from the catalyst surface decreases with the temperature and therefore the $\mathrm{CO}$ oxidation diminishes in favour of the hydrogen oxidation marking the selectivity of the preferential $\mathrm{CO}$ oxidation [52]. However, the selectivity of this type of materials could be notably improved by adjusting some reaction parameters as for example $\mathrm{O}_{2} / \mathrm{CO}$ ratio and/or the space velocity [50].

Overall, the catalysts developed in this study can be categorized as rather efficient solids for the preferential $\mathrm{CO}$ oxidation in $\mathrm{H}_{2}$ rich streams and in the presence of $\mathrm{CO}_{2}$ and $\mathrm{H}_{2} \mathrm{O}$. Very importantly the best $\mathrm{CO}$ oxidation activity is reached at low temperature $\left(100-120{ }^{\circ} \mathrm{C}\right)$ which represents a temperature window that matches pretty well with the working temperature of the PEM-FCs. 


\section{Conclusions}

A series of nanogold based catalysts rather useful for environmental applications have been designed in this work. The prepared catalysts exhibit fairly good activity in the total and preferential CO oxidation reactions. The activity of these materials is guided by the support composition which is the key parameter in the catalytic design. Our data indicate that mesoporous $\mathrm{CeO}_{2}-\mathrm{Fe}_{2} \mathrm{O}_{3}$ mixed oxides are ideal supports for gold nanoparticles. In particular ceria-rich compositions like $\mathrm{Ce}_{0.8} \mathrm{Fe}_{0.2} \mathrm{O}_{2}$ seems to be optimum to achieve the best activity. From the $\mathrm{Ce}-\mathrm{Fe}$ intimate contact some relevant features of the material, as for example the population of oxygen vacancies and the d-band structure, are altered affecting positively to the catalysts performance.

As an additional advantage, the catalysts developed in this study are very effective in the COPrOx reaction under realistic post-reforming streams. Moreover, their activity is maximized at low temperatures matching rather well with the typical operation temperatures of the polymer electrolyte fuel cells converting our systems in an interesting alternative to be further explored in the field of hydrogen economy.

\section{Acknowledgements}

Financial support for this work has been obtained from Junta de Andalucía (TEP-8196) and from the Spanish Ministerio de Economía y Competitividad (ENE2012-374301-C03-01 and ENE2013-47880-C3-2-R) co-financed by FEDER funds from the European Union. The Bulgarian team gratefully acknowledge the financial support by the Bulgarian National Science Fund (Projects DFNI E-01/7-2012 and E-02/2-2014). 


\section{References}

[1] R.J. Farrauto, Y. Liu, W. Ruettinger, O. Ilinich, L. Shore, T. Giroux, Catal. Rev. 49 (2007) 141-196.

[2] M.A. Hickner, H.Ghassemi, Y.S.Kim, B.R. Einsla, J.E. McGrath Chem. Rev. 104 (2004) 4487-4612.

[3] F. Joensen, J. R. Rostrup-Niesen, J. Power Sources 105 (2002) 195-201.

[4] S. Royer, D. Duprez, ChemCatChem, 3 (2011) 24-65.

[5] K.C. Petallidou, A.M. Efstathiou, Appl. Catal. B. 140-141 (2013) 333-347.

[6] N. Bion, F. Epron, M. Moreno, F. Mariño, D. Duprez, Top. Catal. 51 (2008) 76-88.

[7] F. Mariño, G. Baronetti, M. Laborde, N. Bion, A. Le Valant, F. Epron, D. Duprez, Int. J. of Hydrogen Energy 33 (2008) 1345-1353.

[8] G. Avgouropoulos, M. Manzoli, F. Boccuzzi, T. Tabakova, J. Papavasiliou, T. Ioannides V. Idakiev, J. Catal. 256 (2008) 237-247.

[9] R. Burch, Phys. Chem. Chem. Phys. 8 (2006) 5483-5500.

[10] B. Hammer, J.K. Nørskov, Nature 376 (1995) 238-240.

[11] A. Sandoval, L. Delannoy, C. Méthivier, C. Louis, R. Zanella, Appl.Catal. A 504 (2015) 287-294.

[12] S.A.C. Carabineiro, S.S.T. Bastos, J.J.M. Órfão, M.F.R. Pereira, J.J. Delgado, J.L. Figueiredo, Appl. Catal. A 381 (2010) 150-160.

[13] S.A.C. Carabineiro, A.M.T. Silva, G. Dražić, P.B. Tavares, J.L. Figueiredo, Catal. Today 154 (2010) 21-30.

[14] S.A.C. Carabineiro, A.M.T. Silva, G. Dražić, P.B. Tavares, J.L. Figueiredo, Catal. Today 154 (2010) 293-302.

[15] D.L. Trimm, Appl. Catal. A 296 (2005) 1-11.

[16] X. Du, D. Gao, Z. Yuan, N. Liu, C. Zhang, S. Wang, Int. J. Hydrogen Energy 33 (2008) 3710-3718.

[17] G. Avgouropoulos, J. Papavasiliou, T. Ioannides, Catal. Commun. 9 (2008) 1656-1660.

[18] S.A.C. Carabineiro, N. Bogdanchikova, P. B. Tavaresc, J.L. Figueiredo, RSC Adv. 2 (2012) 2957-2965. 
[19] M.A. Soria, P. Pérez, S.A.C. Carabineiro, F.J. Maldonado-Hódar, A. Mendes, Luis M. Madeira, Appl. Catal. A 470 (2014) 45-55.

[20] A. Corma, H. García, Chem. Soc. Rev. 37 (2008) 2096-2126.

[21] T. Tabakova, F. Boccuzzi, M. Manzoli, D. Andreeva, Appl. Catal. A 252 (2003) 385-397.

[22] Z.Y. Yuan, V. Idakiev, A. Vantomme, T. Tabakova, T-Z. Ren, B-L. Su, Catal.Today 131 (2008) 203-210.

[23] L. Pastor-Perez, R. Buitrago-Sierra, A. Sepulveda-Escribano, Int. J. Hydrogen Energy 39 (2014) 17589-7599.

[24] C. Pojanavaraphan, W. Nakaranuwattana, A. Luengnaruemitchai, E. Gulari, Chem. Eng. J. 240 (2014) 99-108.

[25] M.M. Schubert, V. Plzak, J. Garche, R.J. Behm, Catal. Lett. 76 (2001) 143-150.

[26] W. Deng, J. De Jesus, H. Saltsburg, M. Flytzani-Stephanopoulos, Appl. Catal. A 291 (2005) 126-135.

[27] E. Ko, E.D. Park, K.W. Seo, H.C. Lee, D. Lee, S. Kim, Catal. Today 116 (2006) 377-383.

[28] W.Y. Hernández, M.A. Centeno, F. Romero-Sarria, J.A. Odriozola, J. Phys. Chem. C 114 (2010) 10857- 10865.

[29] T.R. Reina, S. Ivanova, M. I. Domínguez, M.A Centeno, J.A Odriozola, Appl. Catal. A 419420 (2012) 58-66.

[30] J.-L. Cao, Y. Wang, T.-Y. Zhang, S.-H. Wu, Z.-Y. Yuan, Appl. Catal. B 78 (2008) 120-128.

[31] T. Tabakova, F. Boccuzzi, M. Manzoli, J. W. Sobczak, V. Idakiev, D. Andreeva, Appl. Catal. B 49 (2004) 73-81.

[32] M.I. Domínguez, M. Sánchez, M.A. Centeno, M. Montes, J.A. Odriozola. Appl. Catal. A 302 (2006) 96-103.

[33] Z. Konya, V.F. Puntes, I. Kiricsi, J. Zhu, J.W. Ager, M.K. Ko, H. Frei, P. Alivisatos, G.A. Somorjai, Chem. Mater. 15 (2003) 1242-1248.

[34] F. Moreau, G.C. Bond, Appl. Catal. A 302 (2006) 110-117.

[35] G. A.Parks, Chem. Rev. 65 (1965) 177-198.

[36]V.V. Pushkarev, V.I. Kovalchuk ,J. L. d'Itri, J. Phys. Chem. B 108 (2004) 5341-5348.

[37]Z. Wu, M. Li, J. Howe, H. M. Meyer III, S. H. Overbury, Langmuir 26 (21) (2010) 1659516606.

[38] R. Q. Long, Y. P. Huang, H. L. Wan, J. Raman Spectroscopy 28 (1997) 29-32. 
[39] S.H. Shim, T.S. Duffy, American Mineralogist 87 (2001) 318-326.

[40] V. Petrovsky, B.P. Gorman, H.U. Anderson, T. Petrovsky, J. Appl. Phys. 90 (2001) 2517252.

[41] M. Schwidder, M. S. Kumar, K. Klementiev, M. M. Pohl, A. Bruckner, W. Grunert, J. Catal. 231 (2005) 314-330.

[42] A. S. Reddy, C. Y. Chen, C. C. Chen, S. H. Chen, C. J. Lin, K. H. Lin, C. L. Chen, S. C. Chang, J. Mol. Catal. A: Chem. 318 (2010) 60-67.

[43] N. Pestryakov, N. Bogdanchikova, A. Simakov, I. Tuzovskaya, F. Jentoft, M. Farias, A. Díaz, Surface Science 601 (2007) 3792-3795.

[44] M.M. Schubert, S. Hackenberg, A.C. van Veen, M. Muhler, V. Plzak, R.J. Behm, J. Catal. 197 (2001) 113-122.

[45] Y.-F. Han, Z. Zhong, K. Ramesh, F. Chen, L. Chen, J. Phys. Chem. C 111 (2007) 31633170.

[46] M. C. Kung, R. Davis, H. H. Kung, J. Phys. Chem. C 111 (2007) 11767-11775.

[47] D. Gamarra, A. Martínez-Arias, J. Catal., 263 (2009) 189-195.

[48] M. Haruta, N. Yamada, T. Kobayashi, S. Iijima, J. Catal. 115 (1989) 301-309.

[49] A. Luengnaruemitchai, S. Osuwan, E. Gulari, Int. J. Hydrogen Energy 29 (2004) 429-435.

[50] T. R. Reina, E. Papadopoulou, S. Palma, S. Ivanova, M.A. Centeno, T. Ioannides, J. A. Odriozola, Appl. Catal. B 150-151 (2014) 554-563.

[51] H.C. Lee, D.H. Kim, Catal. Today 132 (2008) 109-116.

[52] T.R. Reina, C. Megias-Sayago, A. Perez, S. Ivanova, M.A Centeno, J.A Odriozola, J. Catal. 326 (2015) 161-171. 
Table 1 Comparison of textural properties of $\mathrm{Fe}_{(10-\mathrm{x})} \mathrm{Ce}_{\mathrm{x}}$ and $\mathrm{Au} / \mathrm{Fe}_{(10-\mathrm{x})} \mathrm{Ce}_{\mathrm{x}}$ catalysts.

\begin{tabular}{|c|c|c|c|c|c|c|}
\hline Catalysts & $\begin{array}{c}\text { Au } \\
\text { content }^{\mathrm{a}} \\
(w \mathrm{w} . \%)\end{array}$ & $\begin{array}{c}\text { Surface } \\
\text { area } \\
\left(\mathrm{m}^{2} / \mathrm{g}\right)\end{array}$ & $\begin{array}{c}\text { Pore } \\
\text { volume } \\
\left(\mathrm{cm}^{3} / \mathrm{g}\right)\end{array}$ & $\begin{array}{c}\text { Average } \\
\text { pore size } \\
(\mathrm{nm})\end{array}$ & $\begin{array}{l}d_{111} \\
\mathbf{A u}^{b} \\
(\mathrm{~nm})\end{array}$ & $\begin{array}{c}\alpha_{220} \\
\mathrm{CeO}_{2}{ }^{\mathrm{c}} \\
(\mathrm{nm})\end{array}$ \\
\hline $\mathrm{Fe} 0 \mathrm{Ce} 10$ & - & 86 & 0.105 & 2.3 & - & 0.5412 \\
\hline $\mathrm{Fe} 2 \mathrm{Ce} 8$ & - & 118 & 0.281 & 9.2 & - & - \\
\hline $\mathrm{Fe} 4 \mathrm{Ce} 6$ & - & 104 & 0.340 & 12.6 & - & - \\
\hline $\mathrm{Fe} 6 \mathrm{Ce} 4$ & - & 73 & 0.371 & 20.1 & - & - \\
\hline $\mathrm{Fe} 8 \mathrm{Ce} 2$ & - & 68 & 0.351 & 19.8 & - & - \\
\hline $\mathrm{Fe} 10 \mathrm{Ce} 0$ & - & 46 & 0.157 & 8.1 & - & - \\
\hline $\mathrm{Au} / \mathrm{Fe} 0 \mathrm{Ce} 10$ & 2.95 & 69 & 0.104 & 4.7 & 6 & 0.5422 \\
\hline $\mathrm{Au} / \mathrm{Fe} 2 \mathrm{Ce} 8$ & 3.23 & 109 & 0.254 & 8.0 & 5.5 & 0.5370 \\
\hline $\mathrm{Au} / \mathrm{Fe} 4 \mathrm{Ce} 6$ & 3.68 & 93 & 0.315 & 9.9 & 5.8 & 0.5363 \\
\hline $\mathrm{Au} / \mathrm{Fe} 6 \mathrm{Ce} 4$ & 3.35 & 60 & 0.295 & 18.6 & 6.2 & 0.5367 \\
\hline $\mathrm{Au} / \mathrm{Fe} 8 \mathrm{Ce} 2$ & 3.20 & 51 & 0.264 & 24.1 & 6.2 & 0.5392 \\
\hline $\mathrm{Au} / \mathrm{Fe} 10 \mathrm{Ce} 0$ & 2.45 & 39 & 0.151 & 9.2 & n. $\mathrm{d}^{\mathrm{d}}$ & - \\
\hline
\end{tabular}

${ }^{a}$ Analyzed by atomic absorption method.

${ }^{\mathrm{b}}$ average particles size, calculated from Scherrer's equation and (111) crystallographic plane

cunit cell parameter, calculated from the (220) crystallographic plane and Bragg's equation

${ }^{\mathrm{d}}$ not detected $(<5 \mathrm{~nm})$

Table 2 Low Temperature CO oxidation reaction rates inmol $\mathrm{CO} \mathrm{mol} \mathrm{Au}^{-1} \mathrm{~s}^{-1}$ and TOFs values for the gold catalysts at a) $0{ }^{\circ} \mathrm{C}$ and b) $25^{\circ} \mathrm{C}$.

\begin{tabular}{|c|c|c|c|c|c|c|}
\hline Solid & $\begin{array}{l}\text { a) reaction rate } \\
\qquad\left(x 1^{2}\right)\end{array}$ & $\begin{array}{l}{ }^{b)} \text { reaction rate } \\
\left(\times 10^{2}\right)\end{array}$ & $\begin{array}{l}{ }^{\text {a) }} \text { TOF } \\
\left(s^{-1}\right)\end{array}$ & $\begin{array}{l}{ }_{\left(s^{-1}\right)} \text { TOF } \\
\end{array}$ & $\begin{array}{c}\text { Au } \\
\text { particle } \\
\text { size }(\mathrm{nm})\end{array}$ & $\begin{array}{c}\text { Au } \\
\text { dispersion } \\
(\%)\end{array}$ \\
\hline $\mathrm{Au} / \mathrm{Fe} 0 \mathrm{Ce} 10$ & 1.09 & 2.16 & 0.05 & 0.08 & 6 & 22 \\
\hline $\mathrm{Au} / \mathrm{Fe} 2 \mathrm{Ce} 8$ & 5.83 & 8.13 & 0.24 & 0.34 & 5.5 & 24 \\
\hline $\mathrm{Au} / \mathrm{Fe} 4 \mathrm{Ce} 6$ & 4.38 & 7.12 & 0.19 & 0.31 & 5.8 & 23 \\
\hline $\mathrm{Au} / \mathrm{Fe} 6 \mathrm{Ce} 4$ & 1.38 & 3.56 & 0.07 & 0,15 & 6.2 & 21 \\
\hline $\mathrm{Au} / \mathrm{Fe} 8 \mathrm{Ce} 2$ & 1.29 & 3.70 & 0.06 & 0,14 & 6.2 & 21 \\
\hline $\mathrm{Au} / \mathrm{Fe} 10 \mathrm{Ce} 0$ & 0.21 & 0.38 & 0.01 & 0,02 & $5^{*}$ & 26 \\
\hline
\end{tabular}

"For this sample Au diffraction peaks were not observed so that $5 \mathrm{~nm}$ was assumed as average gold particle size. This assumption is made based on the detection limit of the XRD and aiming to avoid a possible overestimation of the TOF.

Figure $1 \mathrm{~N}_{2}$ adsorption-desorption isotherms and pore volume distribution of the prepared materials; A and B) Supports; C and D) Gold based catalysts. (The reader is referred to the web version of the article for interpretation of the color information in this figure legend.)

Figure 2 A) specific surface area as a function of Fe loading; B) gold uptake as a function of Fe content. 
Figure 3 X-ray diffraction patterns of the studied samples. A) Supports; B) Gold based catalysts; C) $\mathrm{Au}(111)$ region.

Figure 4 Raman spectra of the Ce-Fe mixed supports. A) all the supports together; B) detailed spectra of the Fe10Ce0 sample; C) detailed spectra of the Fe0Ce010 support.

Figure 5 UV-Vis study A) supports spectra; B) subtracted spectra: FeXCe (10-X) - Fe0Ce10 ; C) gold based catalysts spectra.

Figure 6 Catalytic activity in the total $\mathrm{CO}$ oxidation. A) Typical light-off run from room temperature to $400^{\circ} \mathrm{C}$; B) low temperature $\mathrm{CO}$ oxidation activity.

Figure 7 Catalytic screening in the preferential CO oxidation (PrOx) A) CO conversion; B) selectivity towards $\mathrm{CO}_{2}$ 


\section{Figure 1}

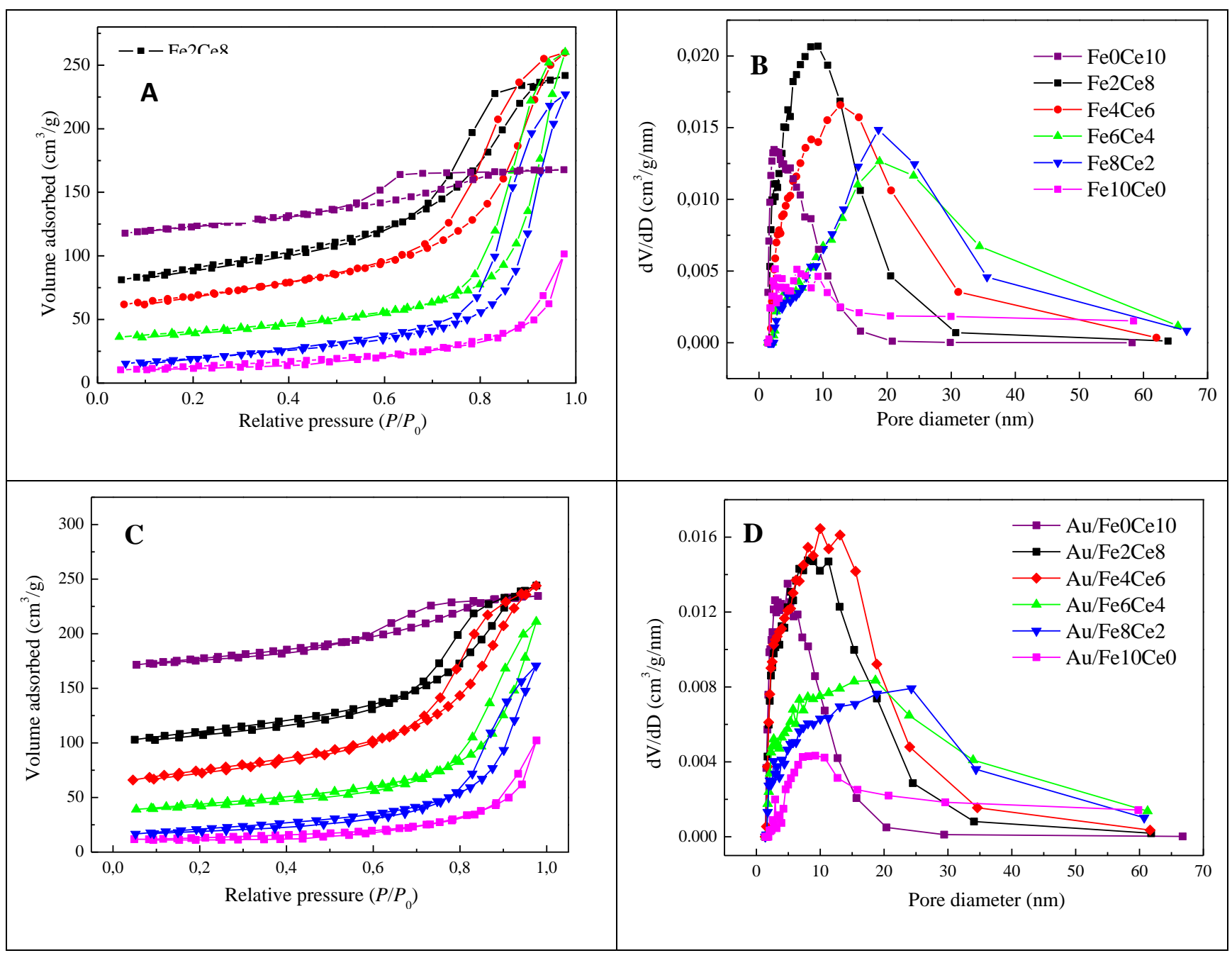


Figure 2
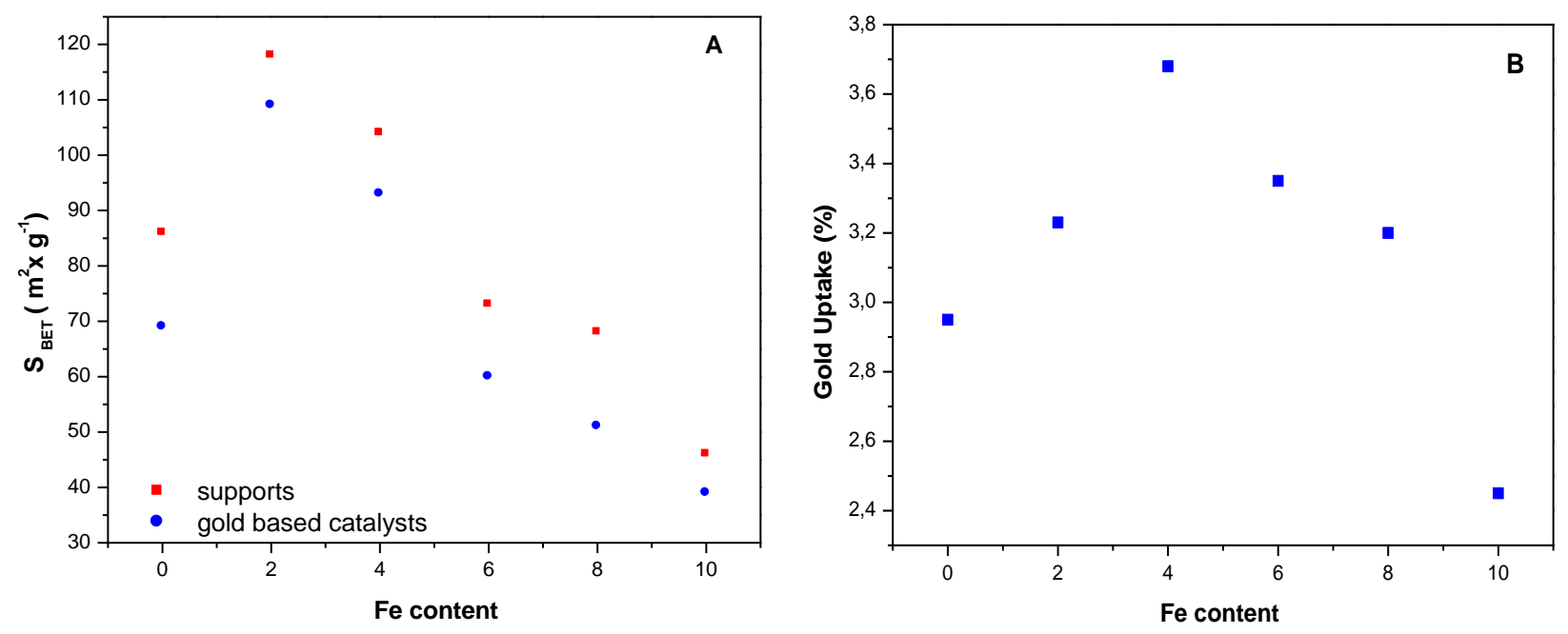
Figure 3
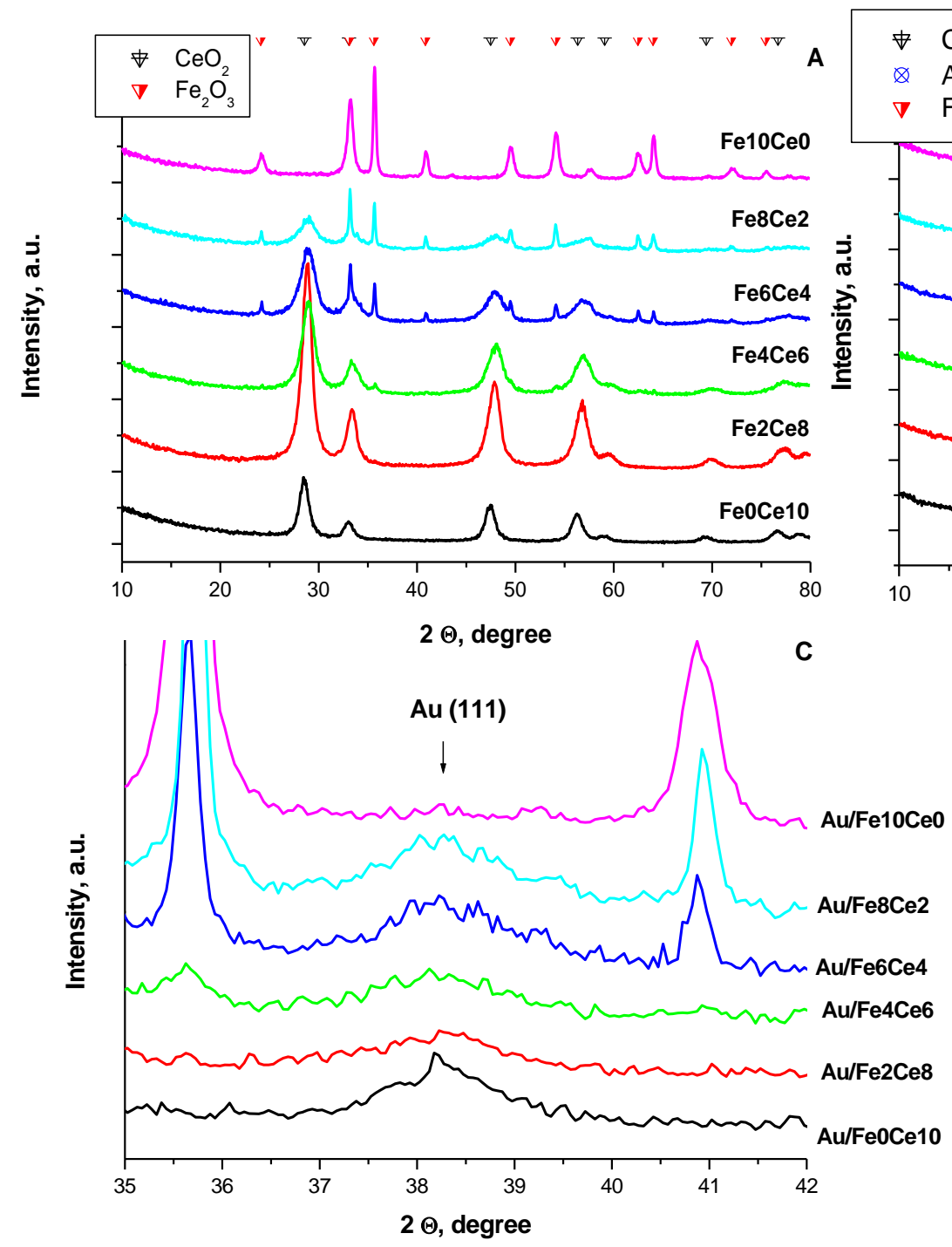
Figure 4

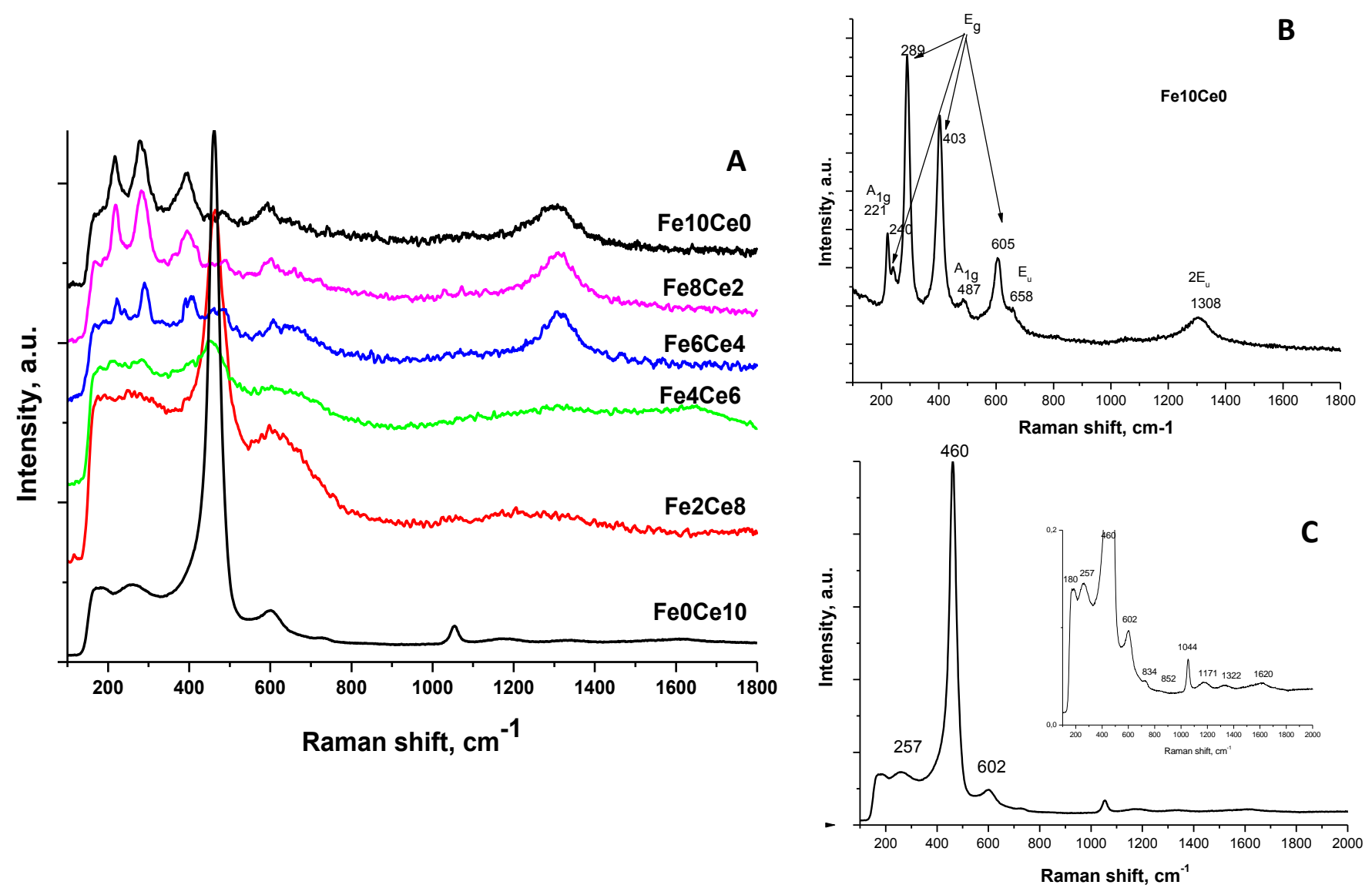




\section{Figure 5}
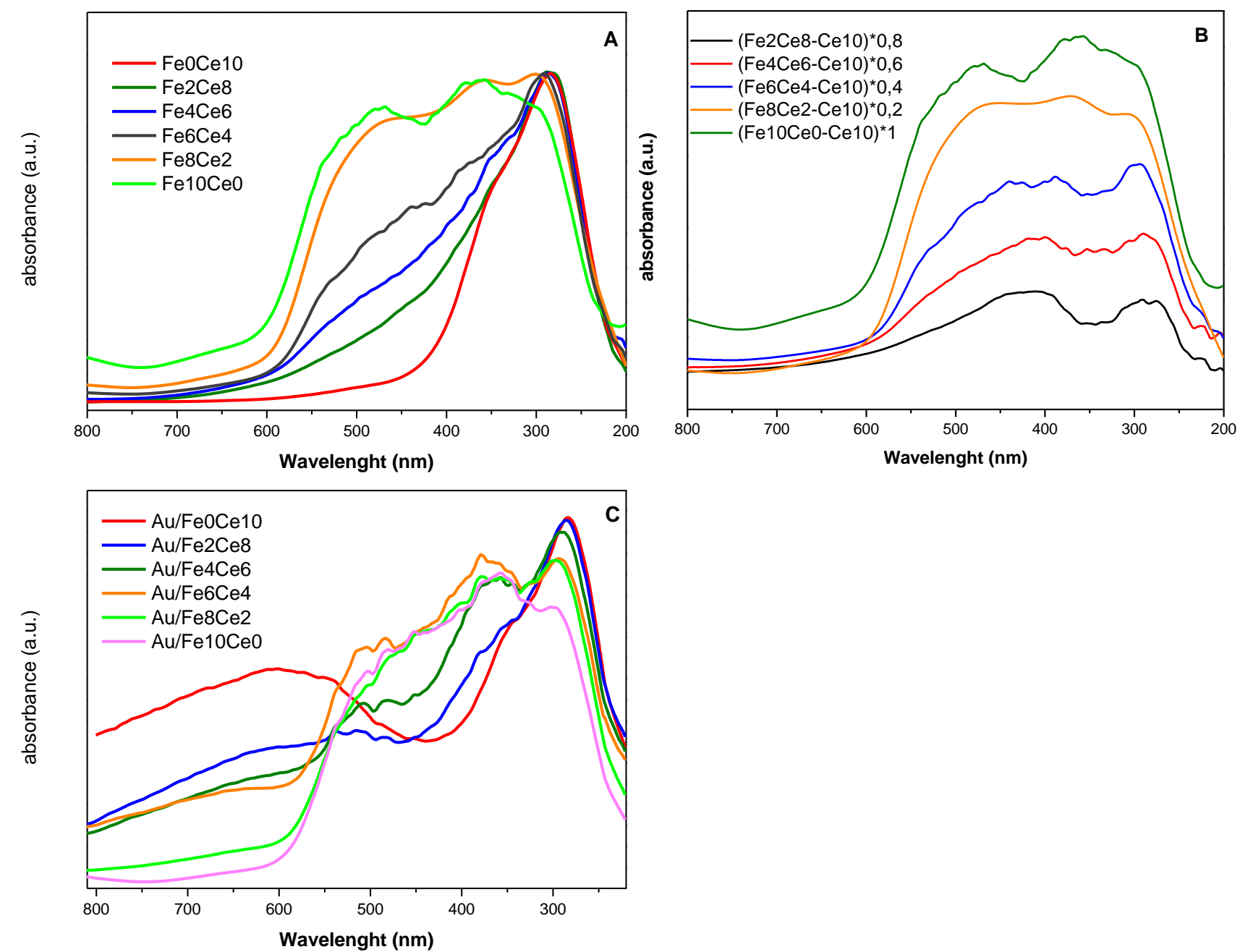


\section{Figure 6}
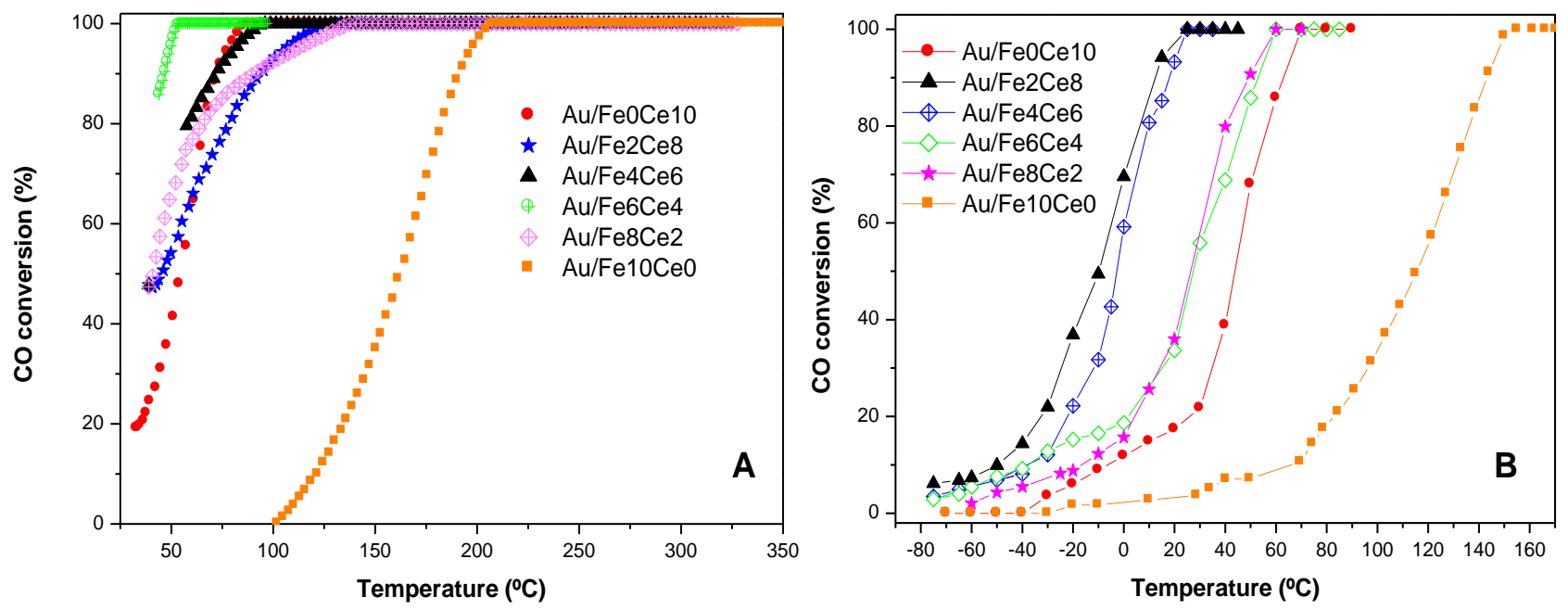
Figure 7
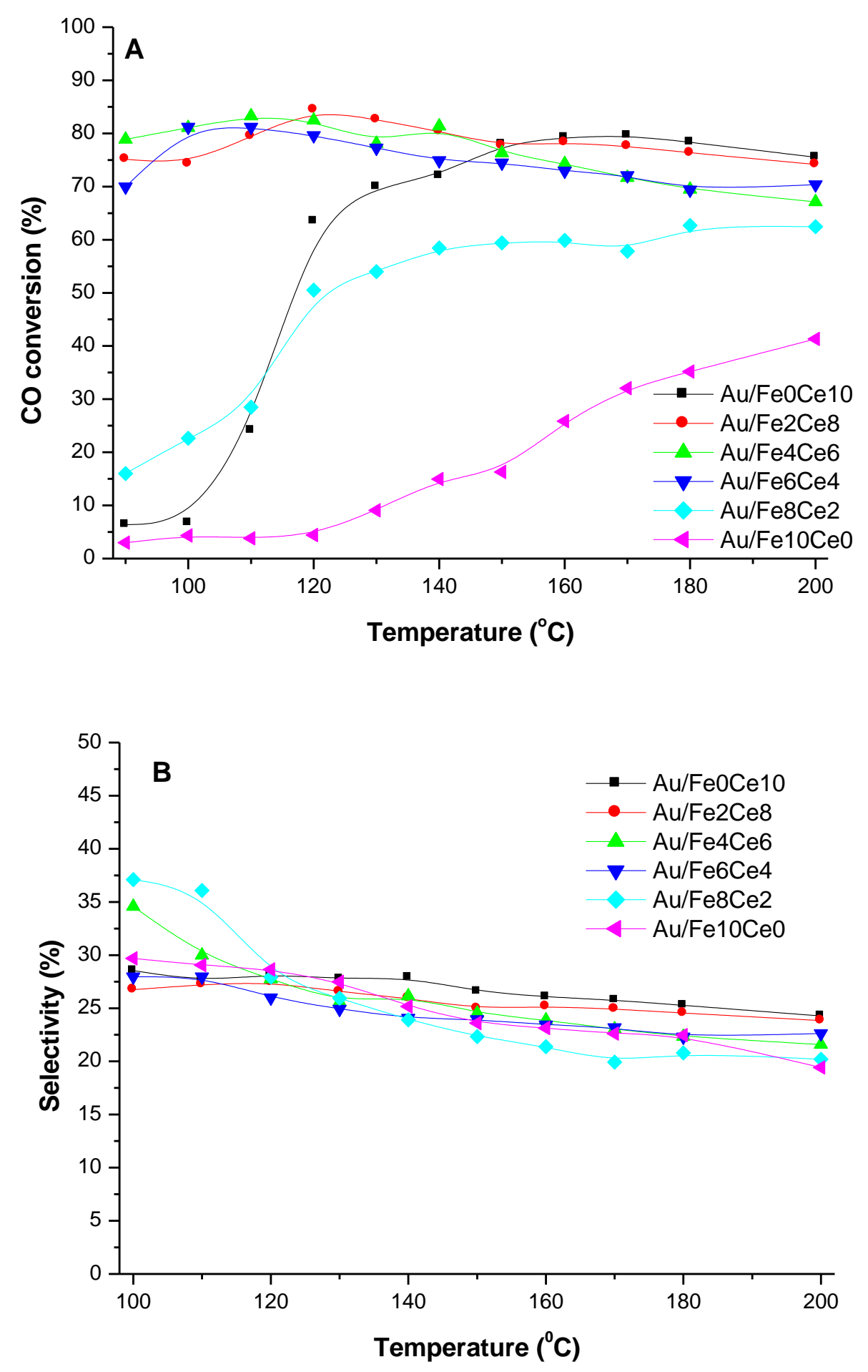